\author{
폴리(비닐 알코올)/사포나이트 나노 복합체 필름 및 연신된 필름의 \\ 열적 성질, 모폴로지, 광학 투명성, 및 기체 투과성 \\ 함미란 $* * *$ · 김정철** • 장진해 $* \dagger$ \\ *금오공과대학교 에너지융합소재 공학부, **한국생산기술연구원 광에너지 융합연구그룹 \\ (2013년 3월 4일 접수, 2013년 4월 12일 수정, 2013년 5월 16일 채택)
}

\title{
Thermal Property, Morphology, Optical Transparency, and Gas Permeability of PVA/SPT Nanocomposite Films and Equi-biaxial Stretching Films
}

\author{
Miran Ham***, Jeong-Cheol Kim**, and Jin-Hae Chang ${ }^{*, \dagger}$ \\ *School of Energy and Integrated Materials Engineering, Kumoh National Institute of Technology, Gumi 730-701, Korea \\ **Energy and Applied Optics Team, Korea Institute of Industrial Technology, Gwangju 500-480, Korea
}

(Received March 4, 2013; Revised April 12, 2013; Accepted May 16, 2013)

\begin{abstract}
초록: 용액 삽입법을 이용하여 다양한 함량의 사포나이트(SPT) 점토를 포함한 폴리(비닐 알코올)(poly(vinyl alcohol), $\mathrm{PVA})$ 나노 복합체 필름을 제조하였다. SPT를 0 에서 $10 \mathrm{wt} \%$ 까지 첨가한 PVA 나노 복합체 필름들의 열적 특성, 모 폴로지, 광학 투명성 및 기체 투과성에 대해 조사하였다. 특히 $5 \mathrm{wt} \% \mathrm{SPT}$ 포함한 PVA 복합체 필름이 매우 우수한 열적 특성과 기체 차단성을 나타내었다. $5 \mathrm{wt} \%$ SPT 포함된 복합체 필름을 연신율에 따라 150 에서 $250 \%$ 까지 이축 연신하였고, 이축 연신율에 따른 점토 분산성, 광학적 특성 및 기체 투과성에 대한 조사를 하였다. 다양한 비로 이 축 연신한 PVA 나노 복합체 필름은 우수한 광학 투명성과 산소 차단성을 보였다.
\end{abstract}

\begin{abstract}
Poly(vinyl alcohol)(PVA) nanocomposite films containing various saponite (SPT) clay contents were synthesized using a solution intercalation method. The thermal property, morphology, optical transparency, and gas permeability of the PVA nanocomposite films with various SPT contents in the range of 0 to $10 \mathrm{wt} \%$ were examined. PVA nanocomposite film containing $5 \mathrm{wt} \%$ SPT showed excellent thermal and gas barrier property. The hybrid films containing $5 \mathrm{wt} \%$ SPT were equibiaxially stretched with stretching ratios ranging from 150 to $250 \%$. The clay dispersion, optical transparency, and gas permeability were also examined as a function of equibiaxial stretching ratio. The PVA nanocomposite films with various equibiaxial stretching ratios showed excellent optical transparency and barrier to oxygen permeability.
\end{abstract}

Keywords: poly(vinyl alcohol), saponite, nanocomposite films, equibiaxial stretching.

\begin{abstract}
서 론
점토(Clay)의 대부분은 층상 실리케이트(phyllosilicate) 구 조로 이루어져 있으며, 일반적으로 층상 구조를 가지는 스멕 타이트계 점토는 실리카 사면체(silica tetrahedral)와 알루미늄 팔면체(aluminaoctahedral)가 2:1 비율로 3층판 구조를 가진 다. ${ }^{1,2}$ 일반적으로 많이 사용되는 스멕타이트계의 점토로 사포 나이트(saponite, SPT)를 비롯해 몬모릴로나이트(montmorillonite, MMT), 헥토라이트(hectorite, SWN), 그리고 마이카 (mica) 등이 있다. 본 실험에서 사용된 SPT의 종횡비(length/ diameter; L/D)는 약 165 이며, 용매에 잘 분산되고, 우수한 팽
\end{abstract}

${ }^{\dagger}$ To whom correspondence should be addressed.

E-mail: changjinhae@hanmail.net
윤성을 가진다. ${ }^{3-6}$ 특히 충전제로서 고분자와 상용성이 뛰어 나 복합재료에 열 안정성, 기계적 특성 및 기체 차단성을 향 상시킨다고 알려져 있다. ${ }^{7-11}$

고분자 중에서도 수용성이라는 특이한 성질을 가지고 있는 폴리(비닐 알코올) (PVA)의 합성은 폴리비닐아세테이트 (poly(vinyl acetate)) 단량체를 중합하고 알칼리 조건에서 검 화(saponification)시켜서 제조한다. ${ }^{12} \mathrm{PVA}$ 는 검화도(degree of saponification, DS)에 따라 점도 및 용해도 등이 많이 달라지 지만, 강한 수소결합으로 인해 높은 기체 차단성을 가지며, 일반 합성수지보다 인장 강도, 항장력, 신장도 및 내마모성이 우수하다. ${ }^{13-16}$ 이로 인해 PVA는 섬유, 필름, 접착제, 표면 처 리제, 코팅 원료 등 다양한 분야에 널리 쓰이고 있다. ${ }^{17,18}$ 그 러나 PVA는 흡습성을 가지므로 기계적 성질과 전기적 성질 등이 외부의 습도에 따라 달라지는 단점이 있다. ${ }^{19-21}$ 
1970년대부터 점토를 이용한 고분자 나노 복합재료에 대해 많은 연구가 시도되어왔다. ${ }^{22-25}$ 고분자에 점토가 균일하게 분 산되었을 때, 인장 강도가 향상되며, 열 안정성 및 내열성 증 가, 내용매성 증가, 우수한 가스 차단성을 보인다. ${ }^{26,27}$ 또한 점 토가 큰 종횡비를 가질 경우 점토들의 고분자 내에서 횡 방 향으로 배열되어 가스가 투과되는 경로의 길이를 증가시켜 기 체 차단성이 우수하며, 열 안정성, 방염성 등의 장점을 가진 다. ${ }^{28}$ 하지만, 대부분 점토가 임계 함량이상 포함될 경우 열 적 특성, 필름의 투명도가 오히려 감소하는 현상을 보였다. ${ }^{29,30}$

이축 연신(biaxial stretching)은 필름에 열을 가하면서, 가로 (X축)방향과 세로(Y축)방향으로 연신시키는 방법이다. 필름 을 이축 연신하는 방법 중 하나는 처음에 필름을 한 쪽 방향 으로 연신 후, 다시 수직 방향으로 연신시키는 방법과 양쪽 방향으로 동시에 연신시키는 방법이 있다. ${ }^{31,32}$ 현재까지 여러 연구 결과에 의하면 이축 연신을 하면 고분자 매트릭스의 결 정화와 모폴로지에 영향을 미친다고 발표가 되어 왔고, 또한 연신되지 않은 복합재료와 연신된 복합재료를 비교하였을 때, 연신된 복합재료가 첨가제의 분산이 더 잘 된다고 보고 되었다. ${ }^{33,34}$

본 연구실에서는 그 동안 $\mathrm{PVA}$ 와 $\mathrm{SPT}$ 를 비롯한 다양한 점 토 및 합성된 유기화 점토를 이용한 나노 복합체를 합성한 후에 열적-광학적 성질, 모폴로지, 및 기계적 성질 등에 관한 결과를 발표하였다. $8,17,24 \mathrm{MMT}$ 를 비롯한 여러 가지 점토 중 SPT는 수분에 분산이 잘되었으며, 특히 PVA와는 수분에서의 상용성 및 분산성이 매우 우수하였다. 얻어진 결과에 의하면 SPT 점토의 함량을 증가시키면 열적 성질 및 기체 투과도, 및 기계적 성질은 증가하였지만, 투명성은 반대로 약간 감소 하였다. 또한 투과 전자 현미경(TEM)을 사용한 점토의 분산 은 대개 $10 \mathrm{~nm}$ 크기 이하로 고루 분산되어 $\mathrm{PVA}$ 에 점토가 나 노 크기로 박리되었음을 알 수 있었다.

본 연구에서는 물에 녹는 수용성 고분자인 PVA 필름에 열 적 특성과 가스 차단성을 향상시키기 위해서 스멕타이트계 점토인 SPT를 첨가제로 사용하였다. 나노 복합재료 제조 방 법 중 하나인 용액 삽입법을 이용하여 필름을 만들었고, 다 양한 점토의 함량 $(0 \sim 10 \mathrm{wt} \%)$ 에 따른 나노 복합체 필름에 대 한 열적 성질, 모폴로지, 광학 투명성 및 가스 차단성을 각각 조사하였다. 또한 기체 차단성과 분산성을 더 높이기 위해서 필름을 $150 \sim 250 \%$ 로 이축 연신하였고, 연신된 필름에 대한 광학적 특성과 산소투과성을 서로 비교하였다.

\section{실 험}

시약. 본 실험에서 사용된 $\mathrm{PVA}$ 는 $\mathrm{SKC}$ 에서 구입한 중합도 (degree of polymerization, DP) 1700이며, 검화도가 85 88\% 인 것을 사용하였다. Tacticity의 구성 성분은 atactic이 $49 \%$, isotactic이 $22 \%$, 그리고 syndiotactic이 $29 \%$ 이었다. ${ }^{35}$ 충전제
로 사용한 $\mathrm{Na}^{+}$사포나이트(SPT)는 Kunimine Inc.에서 구입하 였고, SPT의 CEC(cation exchange capacity)는 70 80 meq/ $100 \mathrm{~g}$ 이었다. PVA 및 점토의 분산 용매로는 증류수를 사용하 였다.

PVA 필름 제조. $250 \mathrm{~mL}$ 플라스크에 증류수 $80 \mathrm{~mL}$ 와 PVA $1.0 \mathrm{~g}$ 을 넣고 $80^{\circ} \mathrm{C}$ 에서 환류하면서 3 시간 동안 격렬하게 교 반하여 완전히 분산시킨다. $10 \times 10 \mathrm{~cm}^{2}$ 유리판 위에 폴리에틸 렌 테레프탈레이트(PET) 필름으로 틀을 만들어 투명하게 녹 은 PVA 용액 $20 \mathrm{~mL}$ 을 캐스팅한다. 캐스팅된 유리판을 $35^{\circ} \mathrm{C}$ 오븐에 넣고, 48 시간 이상 건조시킨다. 완성된 순수한 PVA 필름의 수분을 완벽하게 제거하기 위해서 $80^{\circ} \mathrm{C}$ 진공 오븐에 넣고 24 시간 이상 건조시킨다. ${ }^{36}$

SPT/PVA 나노 복합체 필름 제조. SPT를 다양한 함량 $(0 \sim 10 \mathrm{wt} \%)$ 으로 사용하여 PVA 나노 복합체 필름을 제조하 였다. 필름의 제작 방법은 모두 동일하므로 SPT 함량이 $5 \mathrm{wt} \%$ 일 때만 예로 들어 설명을 하겠다. 시료 병에 $\mathrm{SPT} 0.5 \mathrm{~g}$ 과 증 류수 $100 \mathrm{~mL}$ 를 넣고 온도 $80^{\circ} \mathrm{C}$ 에서 1 시간 동안 교반을 시 킨 후 3 분 초음파 처리하고 15 분 교반의 반복을 5 회하여 분 산시킨다. 얻어진 용액은 약간 불투명하였으나 육안으로는 입 자를 식별하기 어려울 정도로 분산이 잘되었으며, 초음파 처 리 후에는 좀 더 투명하고 고루 분산된 용액을 얻을 수 있었 다. 이와 동시에 $1000 \mathrm{~mL}$ 플라스크에 PVA $9.5 \mathrm{~g}$ 과 증류수 $700 \mathrm{~mL}$ 를 넣고 온도 $80^{\circ} \mathrm{C}$ 로 유지하면서 3시간 동안 교반하 여 완전히 녹인다. SPT가 분산된 용액을 PVA 수용액에 천천 히 한 방울씩 떨어뜨려 $\mathrm{PVA}$ 와 잘 섞이도록 3시간 동안 격렬 하게 교반을 시켜, 균일한 상태의 투명한 용액으로 만든다. 이 용액을 $10 \times 10 \mathrm{~cm}^{2}$ 유리판 위에 PET 필름으로 틀을 만들 어 잘 섞인 투명한 혼합 용액을 $20 \mathrm{~mL}$ 넣고 캐스팅한다. 캐 스팅된 유리판을 $35^{\circ} \mathrm{C}$ 오븐에 넣은 후, 48 시간 이상 건조시 킨다. 이 때, 필름을 빨리 건조시키면 필름에 수축현상이 일 어날 수 있기 때문에 천천히 건조시킨다. 이렇게 완성된 PVA 나노 복합체 필름은 수분을 완전히 제거하기 위해서 $80^{\circ} \mathrm{C}$ 진공 오븐에서 24 시간 건조시킨다.

이축 연신한 PVA 나노 복합체 필름 제조. 용액 삽입법으 로 캐스팅한 PVA 나노 복합체 필름을 $12 \times 12 \mathrm{~cm}^{2}$ 가 되도록 자른다. 준비된 필름을 연신기 안에 넣어 $120^{\circ} \mathrm{C}$ 에서 $1 \mathrm{~mm} / \mathrm{s}$ 씩 양쪽 방향으로 동시에 늘어나도록 하여, 150 250\%로 연 신된 필름을 각각 얻을 수 있었다. 그러나 $300 \%$ 이상 연신 한 필름은 필름의 표면이 균일하지 못하고, 찢어져 얻을 수 가 없었다. 이축 연신기는 필름을 동시에 4방향으로 똑같이 잡아당길 수 있게 Toyo Seiki Seisaku-Sho Ltd.사에서 제작된 $\mathrm{X} 6 \mathrm{H}-\mathrm{S}$ 을 사용하였다.

특성조사. SPT의 층간 거리를 확인하기 위해 사용된 넓은 각 $\mathrm{X}$-선 회절도(wide angle x-ray diffraction, WAXD)는 $\mathrm{Cu}-$ $\mathrm{K} \alpha$ 타겟을 이용하는 PANalytical(Netherland), XPert PRO$\mathrm{MRD}$ 를 사용하였고, $2 \theta$ 값이 $2 \sim 10^{\circ}$ 범위에서 $2 \% \mathrm{~min}$ 의 속도 
로 측정하였다. PVA 나노 복합체 필름의 파단면을 확인하기 위해서 시료를 액체 질소 속에서 파단하여 샘플을 얻어, 전 계 방사형 주사 전자현미경(field emission scanning electron microscopy, FE-SEM: JSM-6500F)으로 측정하였다. 투과 전자 현미경(transmission electron microscopy, TEM)을 측정하기 위해 PVA 시료를 에폭시로 경화시킨 후, $70^{\circ} \mathrm{C}$ 오븐에 24시 간 진공을 걸어준 뒤, 유리칼이 장착된 마이크로톰(microtome) 을 이용하여 두께 $90 \mathrm{~nm}$ 로 시료를 제조하였다. 사용된 TEM 모델은 $\mathrm{EM} 912 \mathrm{OMEGA}$ 이며 가속전압은 $120 \mathrm{kV}$ 로 측정하 였다. PVA 나노 복합체 필름의 열적 특성을 조사하기 위해 사 용한 시차 주사 열량 분석기(differential scanning calorimeter, $\mathrm{DSC}$ : $200 \mathrm{~F} 3, \mathrm{NETZSCH})$ 는 승온 속도 $20^{\circ} \mathrm{C} / \mathrm{min}$ 에 질소 기 류 속에서 측정하였고, 열 중량 분석기(thermogravimetric analyzer, TGA: Auto-TGA Q500)는 승온 속도 $10{ }^{\circ} \mathrm{C} / \mathrm{min}$ 조 건의 질소 기류 속에서 측정하였다. 순수한 $\mathrm{PVA}$ 필름과 나 노 복합체 필름의 광학적 특성을 확인하기 위해서 자외선가시광선 흡광도기(ultraviolet-visible spectrometer, UV-vis.: SHIMADZU UV-3600)를 사용하였고, 황색 지수(yellow index, YI)를 확인하기 위해서 Konica Minolta사의 색차계 (CM-3600D)을 사용하였다. 산소 투과성을 알아보기 위해서 산소 투과도 측정기(oxygen transmission rate tester, $\mathrm{O}_{2} \mathrm{TR}$ : OX-TRAN Model 2/61, Mocon)를 사용하였다.

\section{결과 및 토론}

넓은 각 X-선 회절도. $2 \theta$ 값이 $2 \sim 10^{\circ}$ 범위에서 순수한 $\mathrm{SPT}$ 점토, 순수한 PVA 필름 및 다양한 $\mathrm{SPT}$ 함량에 따른 PVA 복 합체 필름에 대한 X-선 회절도를 Figure 1에 보였다. 분말 상 태의 순수한 SPT의 경우 $2 \theta=6.62(\mathrm{~d}=13.54 \AA)$ 에서 약한 특성 피크를 나타냈다. SPT는 길이와 두께의 비 $(\mathrm{L} / \mathrm{W})$ 가 165 로, 다 른 점토인 $\mathrm{MMT}(\mathrm{L} / \mathrm{W}=218)$ 나 $\mathrm{Mica}(\mathrm{L} / \mathrm{W}=1230)$ 등에 비해 낮은 값을 가지기 때문에 분산된 상태에서 상대적으로 약한

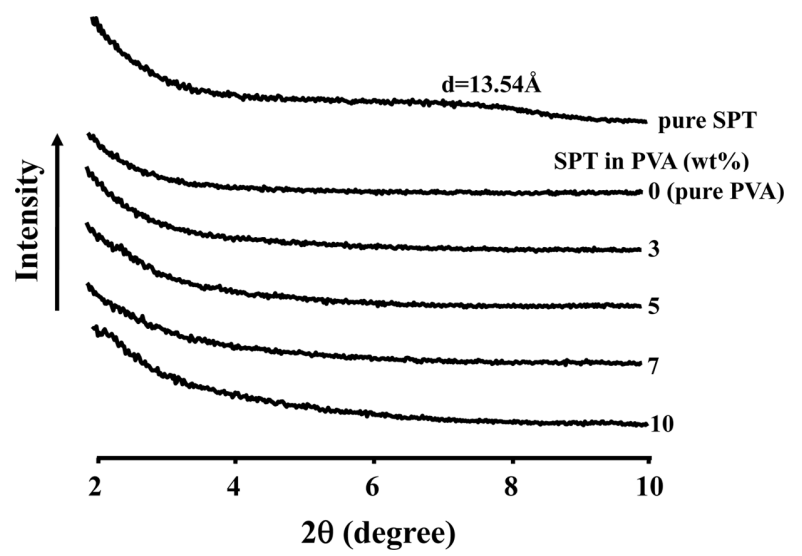

Figure 1. XRD patterns of pristine SPT powder and PVA hybrid films with various SPT contents.
특성 피크를 가지게 된다., ${ }^{9,37}$ 순수한 PVA는 2 10 범위에서 는 특성 피크 $2 \theta$ 값이 나오지 않았으며, 3 10 wt\% SPT 함량 에 따른 PVA 복합체 필름에도 SPT의 특성 피크는 나타나지 않았다. 이로 볼 때, PVA 사슬의 점토 층간 삽입으로 인해 점토 층이 박리(exfoliation) 되어 점토의 층간 거리를 나타내 는 $\mathrm{d}$ 값이 나타나지 않았음을 알 수 있었다. ${ }^{38,39}$ 그러나 점토 의 층간 거리를 확인하기 위해서 X-선 회절도가 주로 많이 사용되지만, 이것은 일차적인 결과일 뿐이고, 점토의 삽입이 나 박리 현상을 관찰하기 위해서는 전자 현미경을 통해서 다 시 확인해야 할 필요가 있다.

모폴로지. 순수한 PVA 필름과 SPT 함량에 따른 PVA 나노 복합체 필름들의 상대적인 파단면 특성을 비교해 보기 위해 서 FE-SEM을 이용하였으며, 점토의 분산된 형태를 보다 자 세히 확인하기 위해 TEM을 사용하였다. 이런 전자 현미경 사진을 통해 앞에서 설명한 XRD결과를 보완할 수 있으며, 동시에 점토의 자세한 모폴로지를 확인할 수도 있다..$^{40,41}$

Figure 2에 보여준 FE-SEM 결과에서는, 점토가 포함되지 않은 순수한 PVA 필름의 파단 면에는 아무런 형태를 확인 할 수 없었지만, 3 10 wt\% SPT를 포함한 PVA 복합체 필름 들에서는 대부분 거친 파단 면을 확인하였다. 또한 $3 \mathrm{wt} \%$ 의 $\mathrm{SPT}$ 가 포함된 PVA 복합체 필름들은 $5-10 \mathrm{wt} \% \mathrm{SPT}$ 가 포함 된 복합체 필름의 사진과 비교하였을 때, 상대적으로 좀 더 부드러운 파단 면을 보여주었다. 이처럼 점토의 함량에 따라 분산 정도와 파단 면의 형태가 다른 것을 확인하였으며, 아 울러 점토의 함량이 일정 임계량보다 많으면 점토끼리 서로 뭉치는 현상을 확인할 수 있었다. 그러나 PVA 매트릭스 고 분자에 대한 점토의 정확한 분산은 $\mathrm{TEM}$ 사진을 통해서 더 자세히 관찰할 수 있다.

Figure 3에 SPT가 3, 5 및 $7 \mathrm{wt} \%$ 포함된 PVA 나노 복합체 의 $\mathrm{TEM}$ 사진을 보였다. 3 과 $5 \mathrm{wt} \%$ 경우(Figure $3(\mathrm{a}-\mathrm{b})$ )에는 (a)

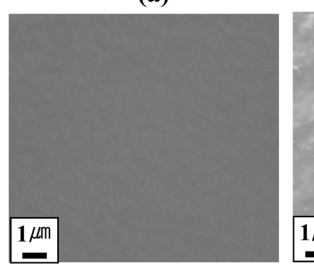

(d)

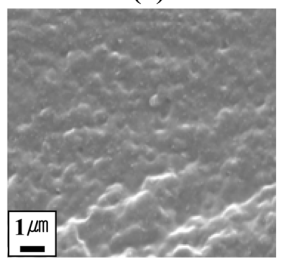

(b)

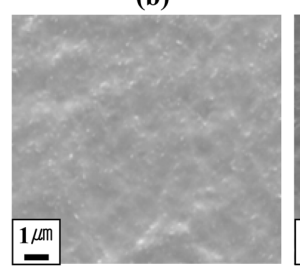

(e)

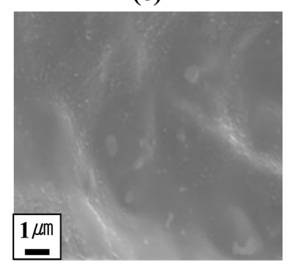

(c)

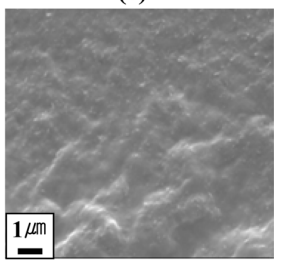

Figure 2. FE-SEM micrographs of PVA hybrid films containing (a) 0 (pure PVA); (b) 3; (c) 5; (d) 7; (e) $10 \mathrm{wt} \%$ SPT. 


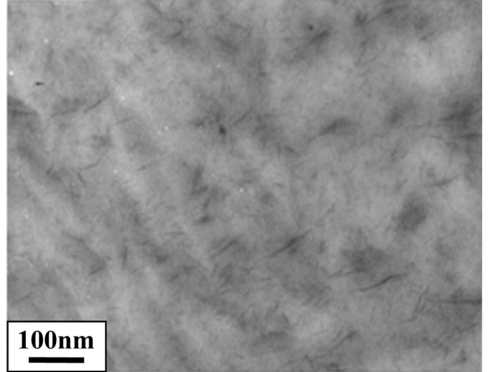

(a)

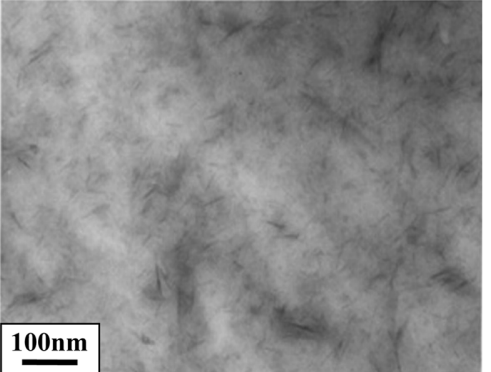

(b)

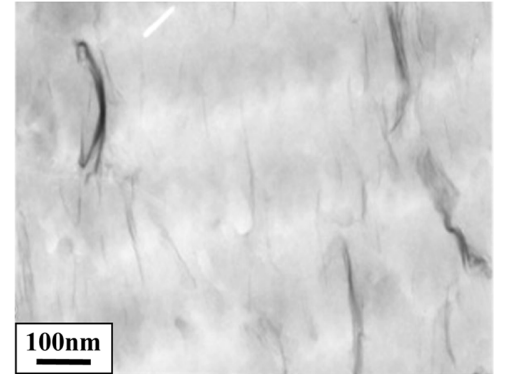

(c)

Figure 3. TEM micrographs of PVA hybrid films containing (a) 3; (b) 5; (c) $7 \mathrm{wt} \%$ SPT.

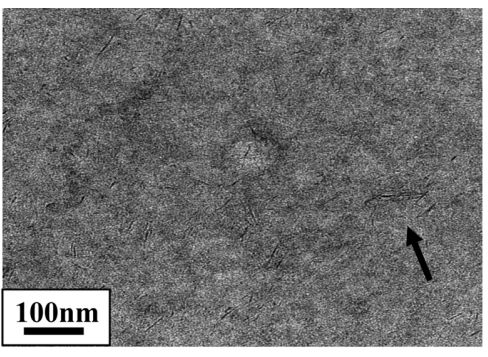

(a)

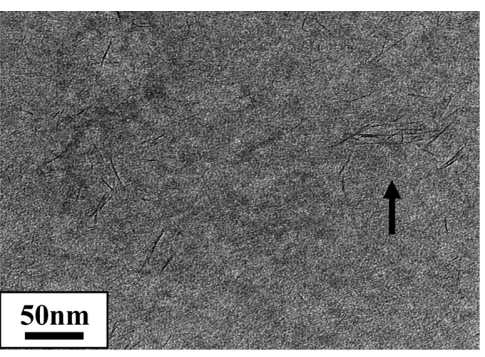

(b)

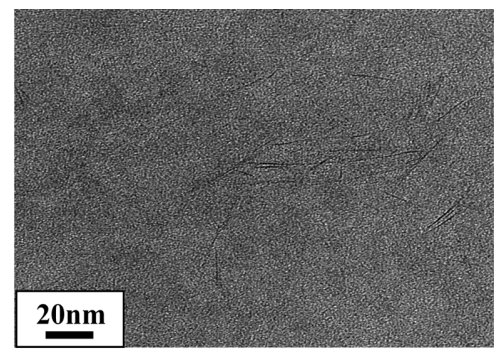

(c)

Figure 4. TEM micrographs of PVA hybrid film containing $5 \mathrm{wt} \%$ SPT with increasing magnification levels from (a) to (c).

PVA에 대부분의 점토가 $10 \mathrm{~nm}$ 두께 이하의 크기로 거의 완 벽하게 박리된 SPT 입자를 확인할 수 있었지만, $7 \mathrm{wt} \%$ 인 경 우(Figure 3(c))에는 점토가 약 $20 \mathrm{~nm}$ 이상으로 뭉쳐있는 부 분을 발견할 수 있었다.

점토 분산을 좀 더 자세히 관찰하기 위해 비교적 분산이 양호한 결과를 보여준 $5 \mathrm{wt} \%$ 의 SPT를 포함하는 PVA 복합 체 필름의 TEM 사진을 배율에 따라 다양하게 Figure 4에 보 였다. 특히 고배율의 경우에는 머리카락 모양의 검은 실 모 양의 점토가 관찰되었으며, 이 결과는 이미 얻은 Figure 1 과 Figure 2의 결과와 일치하였다.

열적 특성. SPT 함량에 따른 PVA 복합체 필름들의 열적 거동을 알아보기 위한 DSC 결과를 Table 1에 정리하였다. 순 수한 PVA 필름의 유리전이온도(glass transition temperature: $T_{\mathrm{g}}$ )는 $69^{\circ} \mathrm{C}$ 이며, 용융온도(melt transition temperature: $T_{\mathrm{m}}$ )는 $165^{\circ} \mathrm{C}$ 이다. ${ }^{42}$ 다양한 $\mathrm{wt} \%$ 의 $\mathrm{SPT}$ 를 포함한 $\mathrm{PVA}$ 복합체 필름 들의 $T_{\mathrm{g}}$ 는 $69 \sim 70^{\circ} \mathrm{C}$ 로 순수한 PVA와 거의 비슷하였다. 하지 만, $T_{\mathrm{m}}$ 의 경우, 3 과 $5 \mathrm{wt} \%$ 가 포함된 복합체 필름들은 각각 172 와 $176^{\circ} \mathrm{C}$ 로 증가하였다. 이렇게 $T_{\mathrm{m}}$ 이 증가한 이유는 점 토가 열을 차단하는 효과가 있어, 고분자 사슬에 열이 전달 되지 않아 결정 거동에 큰 영향을 주기 때문이다. ${ }^{41}$ 그러나 이 와는 반대로 SPT 함량이 $7 \mathrm{wt} \%$ 이상인 PVA 복합체 필름은 오히려 $T_{\mathrm{m}}$ 이 감소하는 효과를 보였다. 예를 들어, $7 \mathrm{wt} \%$ 가 포함된 복합체 필름의 $T_{\mathrm{m}}$ 은 $166^{\circ} \mathrm{C}$ 로 감소하였는데, 이와 같 이 점토가 어느 임계농도 이상이 되면 점토가 고분자에 분산
Table 1. Thermal Properties of PVA Hybrid Films with Various SPT Contents

\begin{tabular}{ccccc}
\hline $\begin{array}{c}\text { SPT in PVA } \\
(\mathrm{wt} \%)\end{array}$ & $T_{\mathrm{g}}\left({ }^{\circ} \mathrm{C}\right)$ & $T_{\mathrm{m}}\left({ }^{\circ} \mathrm{C}\right)$ & $T_{\mathrm{D}}^{\mathrm{i} a}\left({ }^{\circ} \mathrm{C}\right)$ & $w t_{\mathrm{R}}{ }^{600 b}(\%)$ \\
\hline pure SPT & - & - & 142 & 92 \\
0 (pure PVA) & 69 & 165 & 227 & 3 \\
3 & 70 & 172 & 248 & 6 \\
5 & 70 & 176 & 249 & 12 \\
7 & 70 & 168 & 240 & 12 \\
10 & 70 & 166 & 238 & 15 \\
\hline
\end{tabular}

${ }^{a}$ At a $2 \%$ initial weight-loss temperature. ${ }^{b}$ Weight percent of residue at $600^{\circ} \mathrm{C}$.

이 잘 되지 않고 서로 뭉쳐, 오히려 열적 특성이 더 감소하 게 된다. ${ }^{29,30}$ 결국 점토의 함량과 분산 정도에 따라 열적 특 성이 다르다는 것을 확인할 수 있었다. Figure 5 에 각각 다른 $\mathrm{SPT}$ 함량에 따른 PVA 나노 복합체 필름의 DSC 곡선을 보 여주고 있다.

$0 \sim 10 \mathrm{wt} \% \quad \mathrm{SPT}$ 함량에 따른 PVA 나노 복합체 필름들의 열 안정성을 알아보기 위해 TGA를 사용한 결과를 역시 Table 1 에 정리하였고, 이미 설명한 $\mathrm{DSC}$ 의 결과와 마찬가지로 $\mathrm{SPT}$ 의 함량에 따라 초기분해온도(initial decomposition temperature: $T_{\mathrm{D}}^{\mathrm{i}}$ )가 각각 다른 것을 확인하였다. 순수한 $\mathrm{SPT}$ 는 점 토 층 사이에 열에 약한 친수성기를 포함하기 때문에 $T_{\mathrm{D}}{ }^{\mathrm{i}}$ 가 


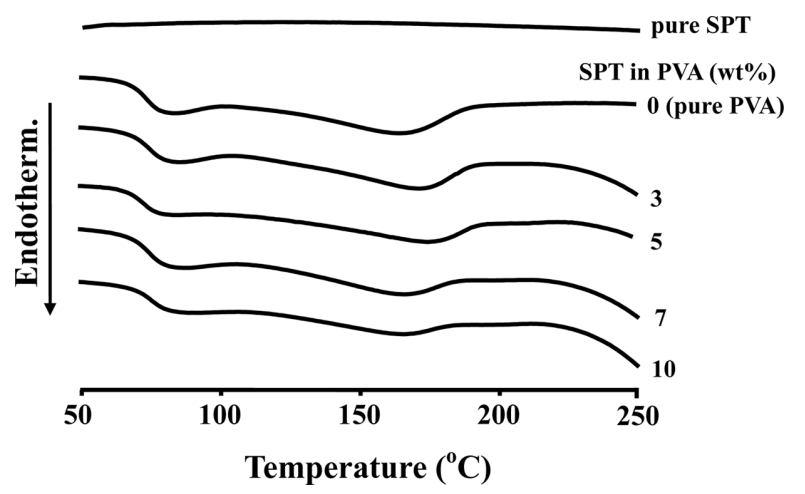

Figure 5. DSC thermograms of PVA hybrid films with various SPT contents.

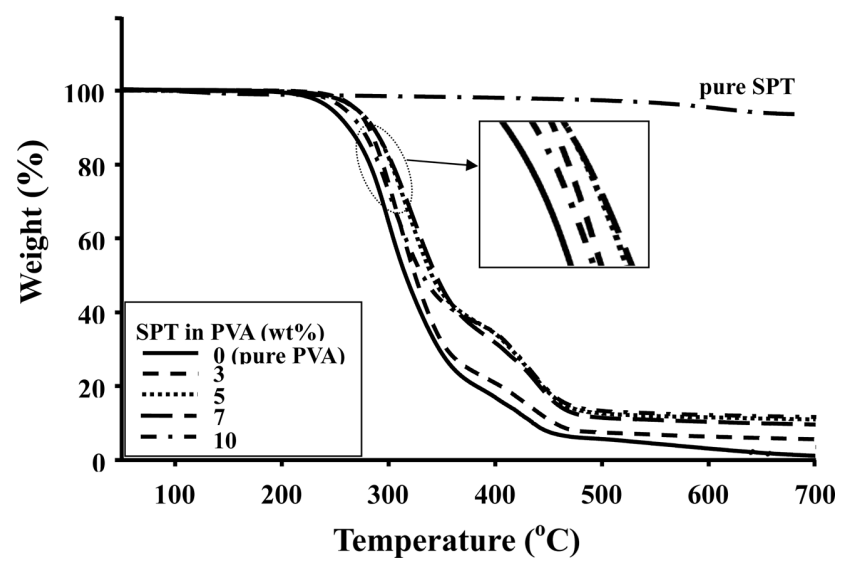

Figure 6. TGA thermograms of PVA hybrid films with various SPT contents.

$150{ }^{\circ} \mathrm{C}$ 미만으로 매우 낮게 나타났다. 3과 $5 \mathrm{wt} \% \mathrm{SPT}$ 포함 한 PVA 복합체 필름들의 $T_{\mathrm{D}}^{\mathrm{i}}$ 는 순수한 $\mathrm{PVA}$ 필름과 비교하 였을 때, $21 \sim 22^{\circ} \mathrm{C}$ 까지 높게 나타났다. 이렇게 $T_{\mathrm{D}}^{\mathrm{i}}$ 가 증가하 는 이유로는 점토가 고분자에 분산되어 열이 이동하는 경로 를 차단시켜 높은 온도로 가열 시, 고분자 성분의 휘발을 억 제했기 때문이다. ${ }^{43,44}$ 하지만, 7과 $10 \mathrm{wt} \% \mathrm{SPT}$ 를 포함한 PVA 나노 복합체 필름들은 앞에서 이미 설명한 바와 같이 점토가 일정 임계 농도 이상이 되어 서로 뭉치고 분산되지 못해 열 안정성의 효과를 발휘하지 못하여 $T_{\mathrm{D}}{ }^{\mathrm{i}}$ 가 $5 \mathrm{wt} \% \mathrm{SPT}$ 포함한 $\mathrm{PVA}$ 복합체 필름에 비해 오히려 낮은 값을 보인다. $600{ }^{\circ} \mathrm{C}$ 에 서 가열 시 $\mathrm{SPT}$ 점토 잔여물 중량 $\left(w t_{\mathrm{R}}{ }^{600}\right)$ 은 $90 \%$ 이상을 보 였지만, 0 10 wt\% SPT 함량을 포함하는 PVA 복합체는 점토 함량에 따라 3 15\%로 일정하게 증가된 값을 보였다. Figure 6 에 다양한 SPT 함량에 따른 PVA 복합체 필름의 TGA 곡선 을 보였다.

광학 투명도. SPT 함량의 따른 PVA 나노 복합체 필름들 의 광학 특성을 알아보기 위해 UV-vis. 흡광도 결과 및 $\mathrm{YI}$ 값을 Table 2에 보였다. 순수한 PVA 필름에 대한 $500 \mathrm{~nm}$ 에
Table 2. Optical Transparency and Oxygen Permeation of PVA Hybrid Films with Various SPT Contents

\begin{tabular}{ccccc}
\hline $\begin{array}{c}\text { SPT in PVA } \\
(\mathrm{wt} \%)\end{array}$ & $\begin{array}{c}\text { Thickness } \\
(\mu \mathrm{m})\end{array}$ & $500 \mathrm{~nm}^{\text {trans }}$ & $\mathrm{YI}^{a}$ & $\begin{array}{c}\mathrm{O}_{2} \mathrm{TR}^{b} \\
\left(\mathrm{cc} / \mathrm{m}^{2} / \text { day }\right)\end{array}$ \\
\hline 0 (pure PVA) & 20 & 91 & 0.12 & 5.13 \\
3 & 20 & 91 & 0.19 & 0.44 \\
5 & 25 & 91 & 0.21 & 0.25 \\
7 & 31 & 91 & 0.26 & 0.63 \\
10 & 20 & 91 & 0.23 & 0.88 \\
\hline
\end{tabular}

${ }^{a}$ Yellow index. ${ }^{b}$ Oxygen transmission rate.

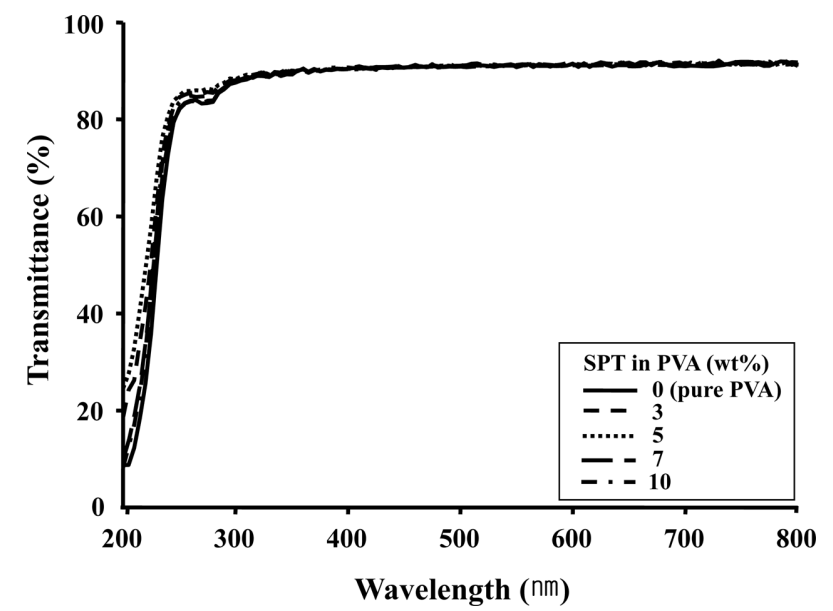

Figure 7. UV-vis. transmittance of PVA hybrid films with various SPT contents.

서의 투과율은 91\%이며, 이 값은 $\mathrm{SPT}$ 가 3 10 wt\% 첨가된 모든 PVA 복합체 필름에서 변화하지 않았고, 아울러 매우 우 수한 광학 투명성을 확인하였다. 이것은 앞의 SEM과 TEM 의 결과를 보았을 때(Figure 2와 Figure 3), 나노 크기 수준으 로 점토가 분산된 경우에는 순수한 PVA와 비슷하게 점토가 고루 분산 및 박리되어 투과율이 좋다는 것을 알 수 있었다. Figure 7에 다양한 SPT 함량에 따른 PVA 복합체 필름의 UVvis 흡수 스펙트럼을 보였다.

순수한 PVA 필름과 3 10 wt \% SPT 함량에 따른 PVA 나 노 복합체 필름들의 YI를 역시 Table 2에 보였다. 순수한 PVA 필름의 $\mathrm{YI}$ 는 0.12 이고, 3 10 wt\% SPT를 포함한 필름들의 $\mathrm{YI}$ 는 $0.19 \sim 0.26$ 이였다. SPT 함량이 높을수록 YI가 증가하는 경 향을 보인다는 것을 확인하였다. 하지만, 육안으로 YI의 차 이를 확인하기가 매우 어려울 정도로 비슷하였다.

필름의 투명성을 시각적으로 확인하기 위해서 Figure 8에 로고가 보이도록 만든 순수한 PVA 필름과 3 10 wt \% SPT 포 함된 PVA 복합체 필름들을 보였다. 모든 PVA 복합체 필름 을 통해서 로고가 매우 선명하게 보였고, 투명도 역시 매우 
(a)

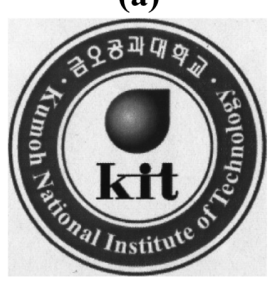

(c)

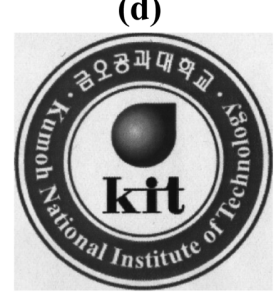

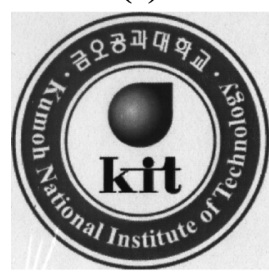

(b)
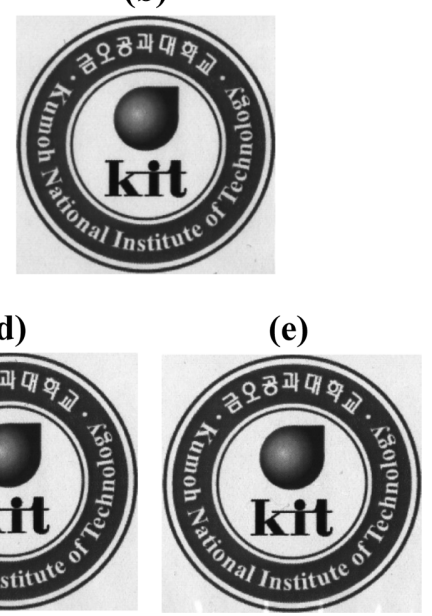

Figure 8. Photographs of PVA hybrid films containing (a) 0 (pure PVA); (b) 3; (c) 5; (d) 7; (e) $10 \mathrm{wt} \%$ SPT.

양호함은 물론이고 순수한 PVA 필름과 비교하였을 때 거의 차이가 없었다.

기체 차단성. 순수한 PVA 필름과 3 10 wt\% SPT 포함된 PVA 나노 복합체 필름의 산소 투과도 결과를 Table 2에 보 였다. 순수한 PVA 필름의 경우 $5.13 \mathrm{cc} / \mathrm{m}^{2} / \mathrm{day}$ 의 산소 투과 율을 보였다. 그러나 순수한 PVA에 SPT를 첨가하였을 때 순 수한 PVA 필름보다 산소 투과율이 현저히 감소하는 것을 확 인하였다. 예를 들어, SPT가 $5 \mathrm{wt} \%$ 포함된 경우에는 기체 투 과성이 $0.25 \mathrm{cc} / \mathrm{m}^{2} / \mathrm{day}$ 까지 매우 낮아졌다. 이것은 점토의 실 리케이트 판상들이 산소의 이동경로를 방해하여 기체 확산 거리가 증가하게 되어, 산소의 투과를 차단함으로써 매우 우 수한 기체 차단성을 보인 것으로 생각된다. ${ }^{4547}$ 그러나 점토 가 어느 임계농도 이상이 되어 7-10 wt\% 포함되었을 때 다 시 기체 투과율은 0.62 에서 $0.88 \mathrm{cc} / \mathrm{m}^{2} / \mathrm{day}$ 로 증가하였다. 그 이유는 SPT 함량이 많을수록 고분자에 분산이 잘 되지 않고 서로 뭉쳐, 오히려 산소 투과가 용이하게 된다.
이축 연신한 PVA 나노 복합체 필름의 모폴로지. 일반적 으로 복합체 필름을 이축 연신하면 충전제의 분산성이 좋아 진다고 알려져 있다. ${ }^{33,34}$ 본 실험에서 이축 연신된 PVA 나노 복합체 필름의 SPT 분산 형태를 증명하기 위해서 $\mathrm{TEM}$ 을 사 용하였다. 점토의 분산성을 극대화하기 위해 $5 \mathrm{wt} \% \mathrm{SPT}$ 를 포함한 PVA 나노 복합체 필름을 $250 \%$ 로 이축 연신한 결과 를 Figure 9에 보였다. 이축 연신하였을 때에는 보다 선명한 점토 입자를 확인할 수 있었고(Figure 9(c)), PVA 매트릭스 안에 대부분의 점토 층이 균일하게 박리되었다는 확인할 수 있었다. 이 결과로 나노 복합체 필름에 이축 연신하였을 때, 고분자 매트릭스 안의 점토 분산에 큰 효과를 준다는 것을 증명할 수 있었다.

이축 연신한 PVA 나노 복합체 필름의 광학특성 및 가스 차단성. 이축 연신율이 각각 다른 $5 \mathrm{wt} \% \quad \mathrm{SPT}$ PVA 나노 복 합체 필름들에 대한 광학 특성을 Table 3 에 정리하였다. $250 \%$ 까지 이축 연신했을 때 $500 \mathrm{~nm}$ 에서의 투과율은 약 $90 \%$ 로 매 우 높은 투과율을 나타내었고, 연신되지 않은 $5 \mathrm{wt} \% \quad \mathrm{SPT}$ 포함한 PVA 나노 복합체 필름과 비교해도 거의 비슷한 값을 보였다. Figure 10에 연신율에 따른 Uv.-vis 결과를 보였다.

$5 \mathrm{wt} \% \quad \mathrm{SPT}$ PVA 나노 복합체 필름의 황색 지수(YI)는 0.21 이었지만(Table 3). 복합체 필름을 150 250 \%까지 이축 연신하여도, $\mathrm{YI}$ 값은 큰 차이를 보이지 않았다(YI=0.13 0.17).

Table 3. Optical Transparency and Oxygen Permeation of PVA Hybrid Films Containing 5 wt\% SPT with Various Equi-biaxial Stretching Ratios

\begin{tabular}{ccccc}
\hline $\begin{array}{c}\text { Biaxial stretching } \\
\text { ratio (\%) }\end{array}$ & $\begin{array}{c}\text { Thickness } \\
(\mu \mathrm{m})\end{array}$ & $500 \mathrm{~nm}^{\text {trans }}$ & $\mathrm{YI}^{a}$ & $\begin{array}{c}\mathrm{O}_{2} \mathrm{TR}^{b} \\
\left(\mathrm{cc} / \mathrm{m}^{2} / \text { day }\right)\end{array}$ \\
\hline 100 (unstretched) & 25 & 91 & 0.21 & 0.25 \\
150 & 22 & 90 & 0.13 & $<10^{-2}$ \\
200 & 20 & 90 & 0.16 & $<10^{-2}$ \\
250 & 19 & 90 & 0.17 & $<10^{-2}$ \\
\hline
\end{tabular}

${ }^{a}$ Yellow index. ${ }^{b}$ Oxygen transmission rate.

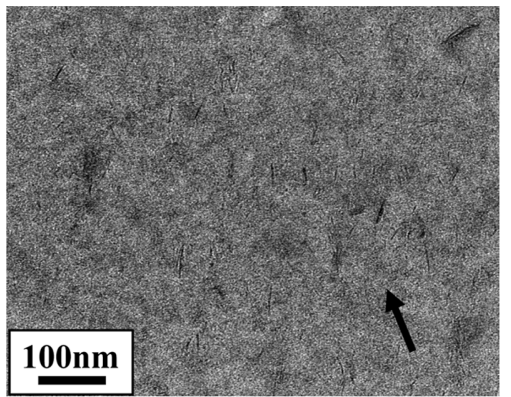

(a)

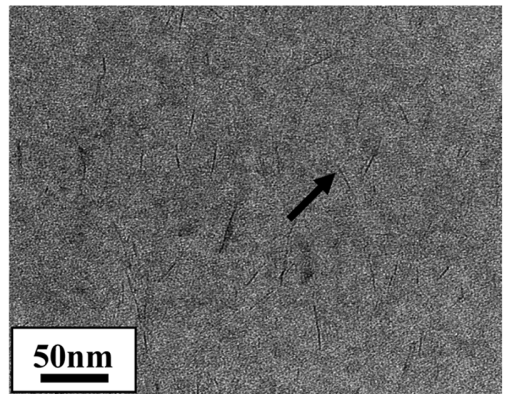

(b)

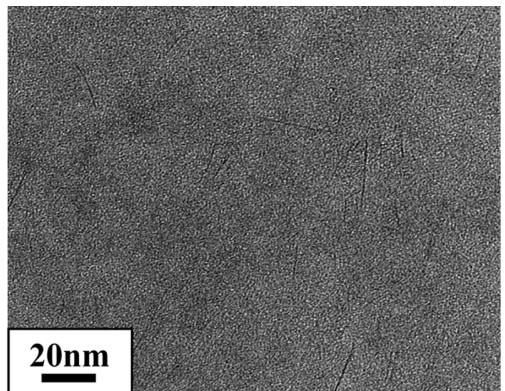

(c)

Figure 9. TEM micrographs of $250 \%$ equi-biaxially streched PVA hybrid films containing $5 \mathrm{wt} \%$ SPT with increasing magnification levels from (a) to (c). 


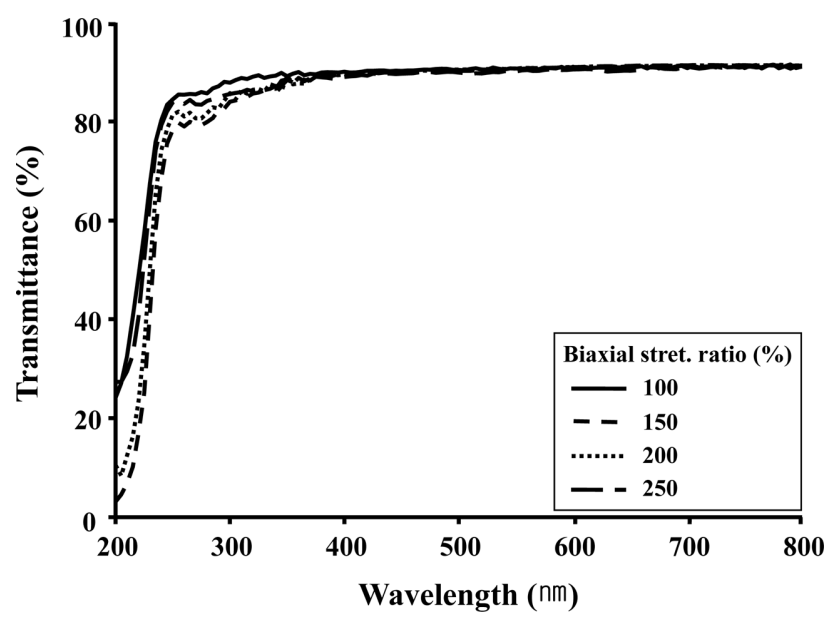

Figure 10. UV-vis. transmittance of PVA hybrid films containing $5 \mathrm{wt} \%$ SPT with various equi-biaxial stretching ratios. (a)

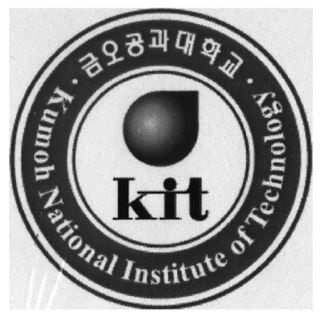

(c)

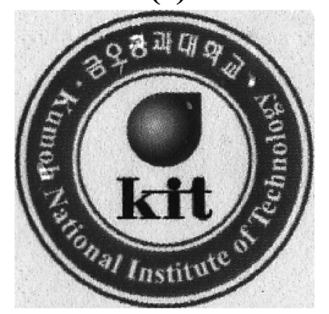

(b)

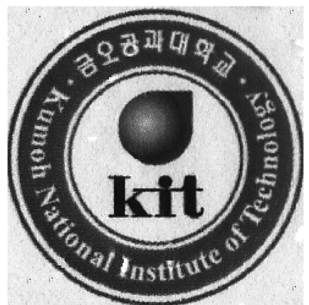

(d)

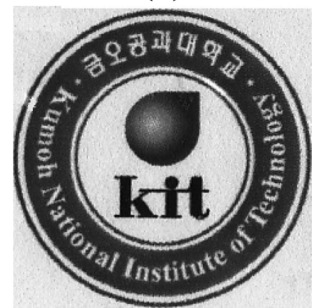

Figure 11. Photographs of PVA hybrid films containing $5 \mathrm{wt} \%$ SPT with various equi-biaxial stretching ratios: (a) 100 (unstretch); (b) 150 ; (c) 200; (d) $250 \%$.

따라서 PVA 나노 복합체 필름의 이축 연신율이 필름의 투명 성에 큰 영향을 미치지 않는다는 것을 확인하였으며, 연신율 증가에 따른 백화 현상도 일어나지 않았다. 이축 연신된 필 름의 투명성을 시각적으로 확인하기 위해서 로고를 통해 본 필름의 사진을 Figure 11에 나타내었다. 이축 연신된 PVA 복 합체 필름을 통해서 로고가 매우 선명하게 보였고, 투명함 역 시 매우 양호함을 알 수 있었다.

$5 \mathrm{wt} \% \mathrm{SPT}$ 를 포함한 PVA 나노 복합체 필름을 이축 연신 하였을 때의 산소 차단성도 Table 3에 나타내었다. 이미 설 명한대로 연신하지 않은 $5 \mathrm{wt} \% \mathrm{SPT}$ PVA 나노 복합체 필름 의 산소 투과율은 $0.25 \mathrm{cc} / \mathrm{m}^{2} / \mathrm{day}$ 이지만, $150 \sim 250 \%$ 까지 연신 된 $\mathrm{PVA}$ 복합체 필름들은 모두 $10^{-2} \mathrm{cc} / \mathrm{m}^{2} / \mathrm{day}$ 이하의 값을 보
였다. 이축 연신을 하면 고분자 매트릭스 안에 점토가 잘 분 산된다는 것을 모폴로지로 확인하였으며, 아울러 연신되지 않 은 PVA 복합체 필름보다 매우 우수한 기체 차단성을 보였 다. 이처럼 가스 차단성이 증가하는 이유는 분산된 점토를 연 신하면 점토의 배향성이 좋아지고, 동시에 일부 뭉쳐있던 점 토 역시 나노 크기로 고루 배향되어 판상 모양의 점토 및 고 분자 복합체의 표면적을 증가시켜 전체적으로 기체 차단성을 향상시키기 때문으로 설명된다. ${ }^{48,49}$ 또한 연신된 복합체 필름 은 보다 견고한 구조로 변하기 때문에 이 효과 역시 차단성 을 높이게 된다..$^{50,51}$

\section{결 론}

수용성 PVA의 열적 특성, 모폴로지, 광학 투명성 및 가스 차단성을 향상시키기 위해서 충전제인 SPT 점토를 사용하여 $\mathrm{PVA}$ 나노 복합체 필름을 제조하였다. FE-SEM의 결과로부터 3 과 $5 \mathrm{wt} \% \mathrm{SPT}$ 포함된 PVA 복합체 필름들은 7 과 $10 \mathrm{wt} \%$ SPT 포함된 필름보다 부드러운 표면을 보였으며, 점토가 고 루 분산된 것을 확인할 수 있었다. 또한 열적 특성도 분산이 잘 된 3 과 $5 \mathrm{wt} \% \mathrm{SPT}$ 포함된 $\mathrm{PVA}$ 복합체 필름들에서 높게 나타났다. $5 \mathrm{wt} \% \mathrm{SPT}$ 를 포함한 $\mathrm{PVA}$ 나노 복합체 필름은 가 장 우수한 열적 성질 및 기체 차단성을 보였으며, 황색 지수 도 순수한 PVA와 큰 차이가 없었다.

점토의 분산성을 향상시키기 위해 $5 \mathrm{wt} \% \mathrm{SPT}$ 포함된 PVA 나노 복합체 필름을 $150 \sim 250 \%$ 까지 이축 연신하였다. TEM 사진으로부터 이축 연신된 나노 복합체 필름의 점토 층이 더 잘 분산되었다는 것을 확인하였고, $250 \%$ 까지 연신했지만 우 수한 광학적 특성에는 변함이 없었다. 기체 차단성 또한 연 신된 $5 \mathrm{wt} \% \mathrm{SPT}$ 포함된 PVA 나노 복합체 필름이 연신되지 않은 필름보다 우수하다는 것을 확인하였다. 결국, 점토의 함 량, 분산 정도 등은 나노 복합체 필름의 특성에 큰 영향을 미 친다는 것을 확인하였다.

감사의 글: 본 연구는 지식경제부 소재원천 기술개발 사업 의 연구비 지원으로 수행되었음.

\section{참 고 문 헌}

1. Y. Fukushima and S. Inagaki, Incl. Phenom., 5, 473 (1987).

2. E. P. Giannelis, Adv. Mater., 8, 29 (1996).

3. A. Usuki, M. Kawasumi, Y. Kojima, A. Okada, T. Kurauchi, and O. Kamigato, J. Mater. Res., 8, 1174 (1993).

4. X. Fu and S. Qutubuddin, Polymer, 42, 807 (2001).

5. E. P. Giannelis, Adv. Mater., 8, 29 (1996).

6. Y. S. Chol and I. J. Chung, Korea Chem. Eng., 46, 23 (2008).

7. F. Suzuki, K. Nakane, and J. S. Piao, J. Mater. Sci., 31, 1335 (1996). 
8. J.-H. Chang, T. G. Jang, K. J. Ihn, W. K. Lee, and G. S. Sur, J. Appl. Polym. Sci., 90, 3208 (2003).

9. P. C. LeBaron, Z. Wang, and T. J. Pinnavaia, Appl. Clay Sci., 15, 11 (1999).

10. J. W. Gilman, Appl. Clay Sci., 15, 31 (1999).

11. Y. Kojima, A. Usuki, M. Kawasumi, and A. Okada, J. Mater. Res., 8, 1185 (1993).

12. J. Bernard, A. Favier, T. Davis, C. B. Kowollik, and M. H. Stenzel, Polymer, 47, 1073 (2006).

13. C. M. Hassan and N. A. Peppas, Adv. Polym. Sci., 152, 37 (2000).

14. M. Levine, G. Iikka, and P. Weis, J. Polym. Sci. Part B: Polym. Chem., 2, 915 (1964).

15. S. M. Tadavarthy, J. H. Moller, and K. Amplatz, Am. J. Roentgenol., 125, 609 (1975).

16. J. Wen, V. J. Vasudevan, and G. L. Wilkes, J. Sol-Gel Sci. Technol., 5, 115 (1995).

17. S. K. Ham, M. H. Jung, and J.-H. Chang, Polymer(Korea), 30, 298, (2006).

18. K. E. Strawhecker and E. Manias, Chem. Mater, 12, 2943 (2000).

19. K. Yano, A. Usuki, T. Kurauchi, and O. Kamigaito, J. Polym. Sci. Part A: Polym. Chem., 31, 2493 (1993).

20. K. Nakane, T. Yamashita, K. Iwakura, and F. Suzuki, J. Appl. Polym. Sci., 74, 133 (1999).

21. W. Y. Chuang, T. H. Yong, W. Y. Chiu, and C. Y. Lin, Polymer, 41, 5633 (2000).

22. N. Ogata, S. Kawakage, and T. Ogihara, J. Appl. Polym. Sci., 66, 573 (1999)

23. T. J. Pinnavaia, Science, 220, 365 (1983).

24. J. H. Yeun, G. S. Bang, B. J. Park, S. K. Ham, and J.-H. Chang, J. Appl. Polym. Sci., 101, 591 (2006).

25. E. Manias, A. Touny, L. Wu, K. Strawhecker, B. Lu, and T. C. Chung, Chem. Mater., 13, 3516 (2001).

26. T. Lan, P. D. Kaviratana, and T. J. Pinavaia, Chem. Mater, 8, 1584 (1996).

27. Y. Kojima, A. Usuki, M. Kawasumi, and A. Okada, J. Mater. Res., 8, 1185 (1993).

28. D. Shi, W. Yu, R. K. Y. Li, Z. Ke, and J. Yin, Eur. Polym. J., 43, 3250 (2007).
29. K. Haraguchi, M. Ebato, and T. Takehisa, Adv. Mater., 18, 2250 (2006).

30. R. Vendamme, S. Y. Onoue, A. Nakao, and T. Kunitake, Nature Mater, 5, 494 (2006).

31. Y. Bin, Y. Tanabe, C. Nakabayashi, H. Kurosu, and M. Matsuo, Polymer, 42, 1183 (2001).

32. Y. Q. Rao, J. Greener, C. A. Avilaorta, B. S. Hsiao, and T. N. Blanton, Polymer, 49, 2507 (2008).

33. S. Jeol, F. Fenouillot, A. Rousseau, V. K Masenelli, C. Gauthier, and J. F. Broiois, Macromolecules, 40, 3229 (2007).

34. Y. M. Kim and J.-H. Chang, Polymer(Korea), 36, 478 (2012).

35. H. Ohgi and T. Sato, Macromolecules, 26, 559 (1993).

36. J. E. Shin, M. R. Ham, J. C. Kim, and J.-H. Chang, Polymer (Korea), 35, 402 (2011).

37. W. F. Jaynes and J. M. Bigham, Clays Clay Miner., 35, 440 (1987).

38. J.-H. Chang, S. J. Kim, and S. Im, Polymer, 45, 5171 (2004).

39. Z. M. Liang, J. Yin, J. H. Wu, Z. X. Qiu, and F. F. He, Eur. Polym. J., 40, 307 (2004).

40. A. B. Morgan and J. W. Gilman, J. Appl. Polym. Sci., 87, 1329 (2003).

41. S. Kumar, J. P. Jog, and U. Natarajan, J. Appl. Polym. Sci., 89, 1186 (2003).

42. C. Liu and Y. Yang, Polym. Test., 28, 801 (2009).

43. H. R. Frischer, L. H. Gielgens, and T. P. M. Koster, Acta Polym., 50, 122 (1999).

44. T. D. Fornes, P. J. Yoon, D. Lunter, H. Keskkula, and D. R. Paul, Polymer, 43, 5915 (2002)

45. J. H. Petropoulos, Adv. Polym. Sci., 64, 93 (1985).

46. J.-H. Chang and K. M. Park, Polym. Eng. Sci., 41, 2226 (2001).

47. D. Jarus, A. Hiltner, and E. Baer, Polymer, 43, 2401 (2002).

48. R. K. Bharadwaj, Macromolecules, 34, 9189 (2001).

49. U. Min, C. S. Yoon, and J.-H. Chang, J. Appl. Polym. Sci., 126, E2 (2012).

50. R. S. Rajeev, E. Harkin-Jones, K. Soon, T. McNally, G. Menary, C. G. Armstrong, and P. J. Martin, Eur. Polym. J., 45, 332 (2009).

51. Y. Ke, C. Long, and Z. Qi, J. Appl. Polym. Sci., 71, 1139 (1999). 